\title{
CONTINUITY \\ AND CHANGE
}

\section{A JOURNAL OF SOCIAL STRUCTURE, LAW AND DEMOGRAPHY IN PAST SOCIETIES}

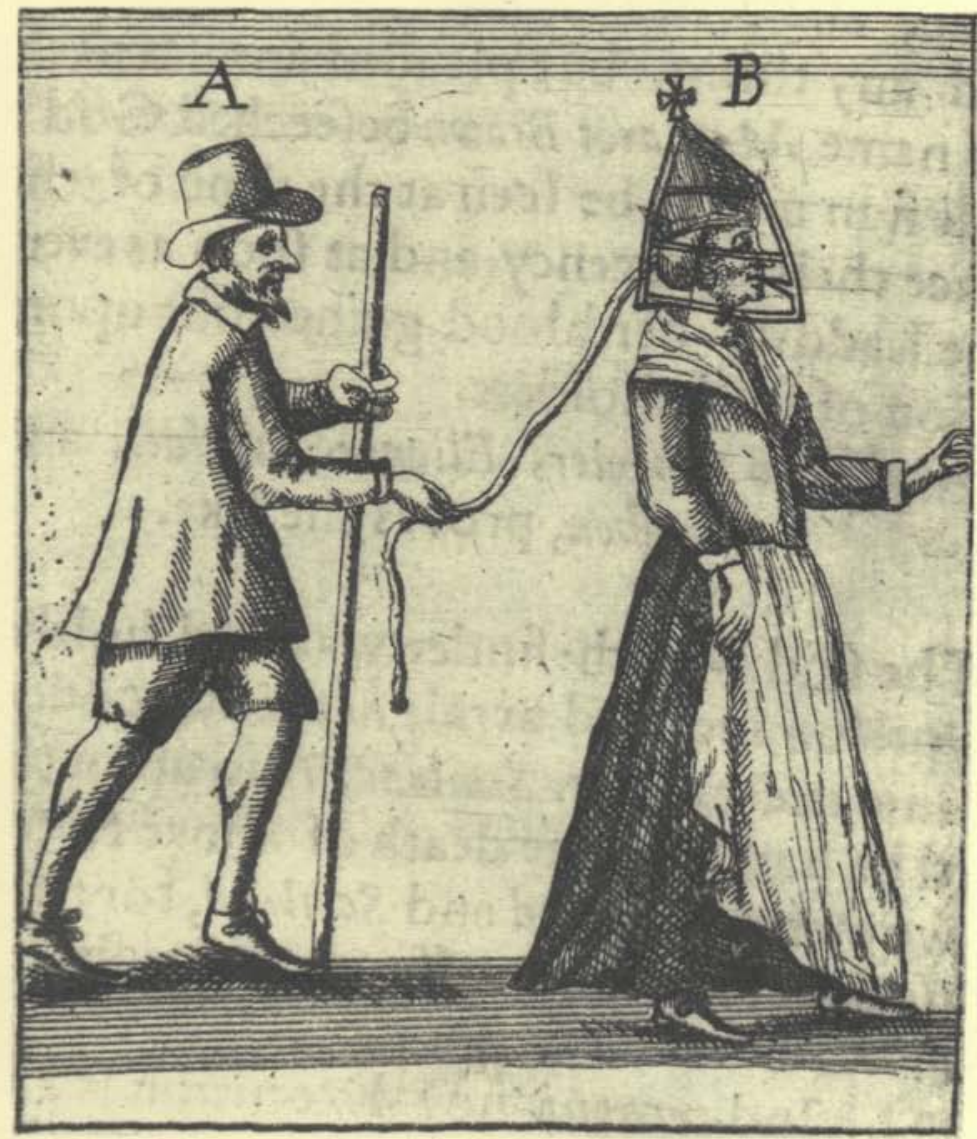

VOLUME 9 PART 3

DECEMBER 1994 


\section{CONTINUITY AND CHANGE}

A journal of social structure, law and demography in past societies.

\section{Tulane University \\ Law School}

\section{Cambridge Group for the History of Population and Social Structure}

EDITORS

LLOYD BONFIELD, Tulane University Law School, Joseph Merrick Jones Hall, New Orleans, Louisiana 70118 , USA

RICHARD WALL, ESRC Cambridge Group for the History of Population and Social Structure, 27 Trumpington Street, Cambridge CB2 IQA, UK

BOOK REVIEW EDITOR

Books for review should be sent to J. BOULTON, Department of History, University of Newcastle upon Tyne, Newcastle upon Tyne NEI 7RU, UK

\section{ASSOCIATE EDITORS}

A. L. ERICKSON, Department of Politics and Contemporary History, University of Salford, Salford M5 4WT, UK

S. C. OGILVIE, Trinity College, Cambridge CB2 ITQ, UK

L. R. POOS, Department of History, Catholic University of America, Washington DC 20064, USA

P. VIAZZo, Istituto degli Innocenti di Firenze, Piazza SS Annunziata 12, 50122 Florence, Italy

\section{G. ALTER, Indiana University}

M. ANDERSON, University of Edinburgh

J. EHMER, Institut für Wirtschafts- und

Sozialgeschichte, Vienna

A. FAUVE, Paris

N. FOLBRE, University of Massachusetts

J. HENDERSON, Wellcome Unit for the

History of Medicine, Cambridge

\section{EDITORIAL BOARD}
P. LASLETT, Cambridge Group
B. MANN, University of Pennsylvania
M. J. MAYNES, University of Minnesota
o. SAITO, Hitotsubashi University
R. S. SCHOFIELD, Cambridge Group
D. SUGARMAN, University of Lancaster
J. WALTER, University of Essex

This journal aims to define a field of historical sociology concerned with long-term continuities and discontinuities in the structure of past societies. Emphasis will be upon studies whose agenda or methodology combines elements from traditional fields such as history, sociology, law, demography, economics or anthropology, or ranges freely between them. There will be a strong commitment to comparative studies over a broad range of cultures and time spans.

Cambridge -University Press express grateful thanks to Tulane Law School for financial support for Contimuity and Change.

\section{SUBSCRIPTIONS}

Continuity and Change (ISSN 0268-4160) is published in volumes of three parts. The subscription price which includes postage (excluding VAT) of volume 9, 1994, is $£ 57$ (US \$90) for institutions; $£ 31$ (US \$48) for individuals ordering direct from the Press and certifying that the journal is for their personal use. Single parts cost $£ 19$ (US \$32) plus postage. US dollar prices apply to the USA, Canada and Mexico. EU subscribers (outside the UK) who are not registered for VAT should add VAT at their country's rate. VAT registered subscribers should provide their VAT registration number. Orders, which must be accompanied by payment, may be sent to a bookseller, subscription agent or direct to the publishers: Cambridge University Press, The Edinburgh Building, Shaftesbury Road, Cambridge CB2 2RU, UK. Orders from the USA, Canada and Mexico should be sent to Cambridge University Press, Journals Department, 40 West 20th Street, New York, NY 10011-4211, USA. Copies of the journal for subscribers in the USA, Canada and Mexico are sent by air to New York to arrive with minimum delay. Japanese prices for institutions (including ASP delivery) are ayailable from Kinokuniya Company Ltd, P.O. Box 55 , Chitose, Tokyo. 